\title{
INTUISI SEBAGAI SALAH SATU SOLUSI MERAIH PRESTASI BELAJAR MATEMATIKA
}

\author{
Sofia Sa'o \\ Prodi Pendidikan Matematika, Fakultas Keguruan dan Ilmu Pendidikan, Universitas Flores Ende \\ Jalan Samratulangi - Ende, Indonesia \\ e-mail: saosofia@yahoo.co.id;
}

corresponding author*

\begin{abstract}
Abstrak
Berbagai masalah matematika seringkali diselesaikan tanpa menggunakan cara-cara yang lazim tetapi menggunakan intuisi. Berpikir intuitif adalah proses kognitif yang mengarah pada ide sebagai strategi untuk membuat keputusan yang menghasilkan jawaban spontan dalam menyelesaikan masalah. Jawaban spontan adalah ekspresi tertulis dan lisan yang membantuseseorang memecahkan masalah matematika tanpa menggunakan cara berpikir analitik. Penelitian ini bertujuan untuk mendeskripsikan berbagai bentuk intuisi yang muncul ketika siswa menyelesaikan masalah matematika. Metode penelitian yang digunakan adalah metode deskriptif kualitatif untuk menggambarkan proses berpikir intuitif siswa melalui instrumen tes dan wawancara. Hasil penelitian menunjukkan bahwa bentuk berpikir intuitif yang muncul adalah (1) intuisi afirmatory yaitu untuk memahami masalah digunakan kognisi langsung dan (2) komponen persepsi dan global, karena siswa melakukan persepsi terhadap solusi jawaban yang akan dihasilkan, kemudian diselesaikan sampai memperoleh hasil. Selain itu, ditemukan juga bahwa berpikir intuitif yang dimunculkan sebagai strategi dalam membuat keputusan didasarkan pada feeling, intrinsik dan intervensi sehingga menghasilkan jawaban pada pemecahan masalah yang dihadapi
\end{abstract}

Kata Kunci: berpikir intuitif, prestasi belajar rendah

\begin{abstract}
Mathematical problems are often solved without using conventional methods but using intuition thinking. Intuitive thinking is a cognitive process that leads to ideas as strategies for making decisions that produce spontaneous answers in solving problems. Spontaneous answers are written and spoken expressions that help a person solve math problems without using analytical thinking. This study aims to describe the various forms of intuition that arise when students solve math problems. The research method used is descriptive qualitative method to describe students' intuitive thinking processes through test instruments and interviews. The results showed that the form of intuitive thinking that emerged was (1) affirmatory intuition, namely direct cognition to understand the problem and (2) perceptual and global components, because students made perceptions of the answer solutions to be generated, then resolved until they got the results. In addition, it was also found that intuitive thinking that is raised as a strategy in making decisions is based on feelings, intrinsics and interventions to produce answers to solving the problems faced
\end{abstract}

Keywords: intuitive thinking, low learning achievement

\section{Pendahuluan}

Pembelajaran matematika menuntut bukan saja siswa yang berpikir tetapi guru juga. Berpikir adalah proses kognitif yang memunculkan ide untuk menyelesaikan masalah berdasarkan informasi (internal ataupun eksternal). Solso (2012) menggolongkan proses berpikir berpikir analitik dan berpikir intuitif. Hipotesis dihasilkan melalui berpikir intuitif, digunakan sebagai dasar kemudian berpikir analitik akan digunakan untuk pembuktiannya. Berpikir intuitif dapat digunakan jika seseorang mengalami kesulitan dalam pemecahan masalah secara analitik. Seperti contoh menyelesaikan soal dalam penelitian ini yaitu 2012×2010-2009×2013. Masalah ini akan membutuhkan waktu lama jika diselesaikan secara analitik, namun akan mudah diselesaikan dengan cara intuitif yaitu dengan mengoperasikan dua angka belakang dari setiap kelompok bilangan yang diketahui.

Sa"o (2015) mengatakan bahwa terdapat 3 faktor yang mendukung munculnya berpikir intuitif seseorang saat mengalami kesulitan dalam pemecahan masalah yaitu; berdasarkan 1) feeling, 2) intrinsik dan 3) intervensi. Feeling adalah ide yang muncul dalam pikiran seseorang yang 
dikaitkan dengan masalah sehingga dihasilkan jawaban spontan dan menjadi keputusan. Intrinsik, artinya bahwa ide muncul dalam pikiran seseorang dengan tiba-tiba, yang menjadi strategi untuk membuat keputusan sehingga menghasilkan jawaban spontan, dan ini terjadi masih berkaitan dengan feeling. Intervensi, artinya strategi yang tiba-tiba muncul dalam pikiran seseorang, berkaitan dengan pengetahuan sebelumnya dan menjadi strategi untuk menghasilkan jawaban spontan dalam melakukan pemecahan masalah. Intervensi yang terjadi ini juga masih berkaitan dengan feeling.

Berpikir intuitif diidentikkan dengan pemikiran spontan. Menurut Peter (2008) intuisi adalah jawaban spontan yang didasarkan pada konstelasi luas pengalaman masa lalu, pengetahuan, keterampilan, persepsi dan perasaan. Intuisi adalah pusat semua keputusan dimana informasi telah tersimpan dalam memori jangka panjang. Kecerdasan tersembunyi yang muncul secara spontan saat seseorang menyelesaikan masalah disebut Weintraub (1998) sebagai intuisi. Di lain pihak Fischbein (1987) mendefinisikan intuisi sebagai proses kognitif yang terjadi secara tiba-tiba dan spontan berkaitan dengan skemata yang telah dimiliki.

Fischbein membagi instuisi menjadi dua bagian, afirmatory yaitu masalah dipahami secara intuisi dan antisipatory yaitu masalah diselesaikan dengan intuisi. Kedua jenis ini harus berjalan dalam pemecahan masalah, sehingga memperoleh hasil yang maksimal. Dalam memecahkan masalah matematika, terkadang sudah ada sesuatu yang tanpa pemikiran secara mendalam digunakan untuk menyelesaikannya, walaupun sesuatu tersebut belum tentu dapat dibuktikan kebenarannya. Sebagai contoh, untuk membuktikan kebenaran pernyataan matematika, biasanya pada saat awal akan berpikir secara sepintas (spontan) cara pembuktian yang digunakan, apakah bukti langsung atau tidak langsung, ini merupakan ciri berpikir intuitif.

Pemecahan masalah matematika merupakan bagian penting dari proses pembelajaran matematika. Pemecahan masalah memungkinkan siswa menggunakan pengetahuan dan keterampilan yang sudah dimilikinya. Pemecahan mesalah membutuhkan kemampuan berpikir tinggi. Untuk memecahkan masalah matematika diantaranya dapat dilakukan dengan cara berpikir analitik, dapat juga dengan cara berpikir intuitif.

Usodo (2011) mengatakan bahwa dalam menentukan strategi pemecahan masalah berpikir intuitif memiliki peran penting karena gagasan kreatif muncul sebagai akibat intuisi siswa. Caracara cerdas sering digunakan oleh siswa pandai untuk menghasilkan solusi yang akurat dan singkat. Hal ini sesuai dengan tuntutan kurikulum 2013 yang mensyaratkan bahwa dalam pembelajaran matematika kreativitas sangat diperlukan. Menurut Kustos (2010), pemecahan masalah yang tidak dianalisis adalah ciri berpikir intuitif.

Intuisi setiap orang berbeda-beda, sehingga dalam pemecahan masalah matematika, intuisinya sendiri yang harus diandalkan. Solusi setiap siswa akan yang berbeda sebagai akibat intuisi yang berbeda tersebut. Mungkin ada pemikiran yang sama, namun kesamaan itu jarang terjadi, walaupun akan menghasilkan jawaban sama dan benar. Jadi pemecahan masalah dengan menggunakan berpikir intuitif memiliki banyak solusi jawaban berdasarkan pada pemikiran seseorang dan strategi yang digunakan dalam memecahkan masalah tersebut. Cara berpikir yang dilakukan seseorang mungkin tidak identik dengan cara berpikir orang lain, namun hasil pemecahannya dapat dipahami oleh orang lain. Dalam pemecahan masalah matematika, berpikir intuitif sering terjadi namun guru ataupun siswa tidak menyadarinya.

Untuk mengkaji munculnya berpikir intuitif siswa dalam pemecahan masalah matematika, maka peneliti melakukan observasi awal di sekolah. Hasil observasi menunjukkan bahwa jawaban spontan diberikan oleh banyak siswa, tanpa melakukan analisis terhadap jawabannya terlebih dahulu. Bagi peneliti, benar atau salah tidaklah penting, yang terpenting adalah siswa sudah menggunakan intuisinya, dengan menjawab spontan. Spontan yang dimaksudkan adalah jawaban langsung diberikan siswa, yang memberikan beberapa kemungkinan, antara lain informasi yang diterima siswa dikaitkan dengan pengetahuan yang telah diperolehnya dan telah tersimpan dalam memori siswa sehingga jawaban yang dihasilkan tidak perlu dibuktikan. Kemungkinan lain adalah ketika pemikiran muncul secara tiba-tiba, jawaban langsung diberikan. Hal ini terbukti dari hasil wawancara peneliti dengan siswa yang bersangkutan saat setelah pembelajaran. Siswa tersebut mengatakan bahwa jawabannya tadi adalah pikirannya yang dikaitkan dengan pengetahuan yang mirip dengan apa yang pernah diperolehnya waktu di SD. Panca indera menjadi media masuknya informasi masalah dari lingkungan eksternal ke pikiran pada proses berpikir intuitif. Otak/pikiran akan memproses informasi tersebut dan menghasilkan solusi. Solusi akan kembali ke lingkungan eksternal melalui 
effectors yang berupa jawaban spontan. Seseorang yang menggunakan intuisi nampak melalui penglihatan dan pendengarannya.

Berpikir intuitif merupakan pemikiran non analitik namun berkaitan erat dengan matematika. Matematika adalah ilmu pengetahuan yang memiliki struktur bangunan yang ketat, terdiri atas aksioma, definisi, aturan dan teorema dengan suatu struktur logika (Taplin, 2010). Berpikir matematika diproduksi melalui proses analisis formal didasarkan pada logika dan bukti matematika.

Menurut Voskoglou (2006) intuisi dan formalitas sangat berperan penting dalam pemecahan masalah matematika. Matematika formal didefinisikan secara ketat dan melalui teorema-teorema terkait. Siswa sangat memerlukan berpikir intuitif jika mengalami masalah dalam proses pembuktian formal. Fischbein (1987) memberikan contoh praktis tentang berpikir intuitif dalam matematika, yaitu:

\section{Jika $A=B$ dan $B=C$ maka $A=C$}

Ini secara intuitif dapat dipahami dengan jelas. Namun jika dibuktikan secara analisis A, B dan $\mathrm{C}$, merupakan suatu nilai dari hasil operasi aljabar. Contoh lain yang dapat diterima secara intuitif seperti himpunan bilangan asli dan himpunan bilangan positif adalah setara. Menurut Fischbein (1987) dua himpunan dikatakan setara sebagai berikut.

"This is intuitive knowledge - a kind of knowledge which is not based on sufficient empirical evidence or on rigorous logical arguments and, despite all this, one tends to accept it as certain and evident".

Secara analitik contoh dua himpunan setara tersebut harus menggambarkan fakta bahwa elemen-elemen dalam himpunannya memiliki kepastian dan konsisten.

Berpikir intuitif sering digunakan dalam pemecahan masalah matematika seperti diungkapkan oleh Kustos (2010) intuisi dapat menjadi alasan pemahaman yang kuat dalam hubungannya dengan logika bukan melawan logika. Suatu pernyataan matematika memerlukan bukti, tetapi bukti dari pernyataan sering menggunakan intuisi untuk menentukan apa pola membuktikan pernyataan tersebut. Selanjutnya diungkapkan oleh Poincare (2007), bahwa pemecahan masalah matematika membutuhkan intuisi untuk melengkapi berpikir analitik. Poincare mencontohkan yaitu pernyataan sudut selalu dapat dibagi, ini adalah kebenaran yang dipikir dengan intuisi langsung. Siapa yang bisa meragukan bahwa sudut selalu dapat dibagi menjadi sejumlah bagian yang sama? Contoh lain yang dapat dipahami dengan berintuisi dalam matematika, jika pada garis lurus terdapat titik C yang terletak diantara titik A dan titik B dan titik D diantara titik A dan C, maka titik D juga terletak antara titik A dan B.

Berdasarkan penjelasan di atas, maka penelitian ini bertujuan untuk mendeskripsikan berpikir intuitif siswa yang muncul dalam menyelesaikan masalah matematika.

\section{Metode Penelitian}

Penelitian ini adalah penelitian deskriptif dengan pendekatan kualitatif (Creswell, 2012). Berdasarkan tujuan penelitian, penelitian ini bertujuan untuk mengungkap atau memperoleh gambaran tentang proses berpikir intuitif yang digunakan siswa, peneliti mengeksplorasi cara berpikir subjek secara mendalam berkaitan dengan apa yang ditulis, diucapkan atau bahkan apa yang dipikirkan mereka pada saat menjawab pertanyaan, dan menyelesaikan soal matematika melalui wawancara. kegiatan:

Langkah-langkah penelitian ini meliputi

a. Observasi awal

Kegiatan ini dilakukan beriringan dengan ujicoba soal untuk memperoleh informasi kondisi siswa yang berpikir intuitif dalam menyelesaikan soal matematika, dimana informasi ini akan digunakan sebagai pertimbangan peneliti untuk menetapkan tingkat kemampuan berpikir subjek penelitian.

b. Tahapan Persiapan

Kegiatan yang dilakukan adalah: (1) Membuat instrumen penelitian berupa soal pemecahan masalah matematika dan pedoman wawancara; (2) Menyiapkan alat bantu pengambilan data, terutama alat perekam suara seperti; flash disk, dan camera;(3) Menyusun jadwal penelitian, dan mengkoordinasikan langsung dengan subjek yang bersangkutan.

c. Tahapan Pelaksanaan Penelitian dan Analisis Data

Pada tahap ini, peneliti memberikan masalah matematika yang telah divalidasi kepada subjek penelitian kemudian masing-masing siswa diwawancarai. Data tersebut kemudian dianalisis 
Data yang dikumpulkan dalam penelitian ini bersifat deskriptif meliputi data observasi, dan data verbal berupa data yang diperoleh dari jawaban penyelesaian soal dan wawancara. Subjek penelitian adalah siswa kelas VIII SMP yang terdiri 4 orang berdasarkan kemampuan berintuisi dalam pemecahan masalah matematika. Adapun alasan pemilihan 4 siswa ini dikarenakan peneliti mendapatkan data jenuh atau jawaban hampir sama dari 30 siswa yang diteliti. Subjek penelitian yang merupakan siswa-siswa SMP dari 6 sekolah yang ada di Kota Ende. Dalam penelitian ini peneliti memberikan 1 soal untuk dikerjakan oleh subjek penelitian.

Kriteria pemilihan subjek adalah (1) Subjek adalah siswa berkemampuan matematika tinggi berdasarkan informasi guru, karena peneliti beranggapan bahwa siswa tersebut mampu berpikir intuitif dengan baik; (2) Hasil tes kemampuan berintuisi berupa 2 soal pemecahan masalah. Instrumen penelitian berupa soal matematika seperti terlihat berikut:

Berapakah hasil dari penjumlahan $202010 \times 202012-202009 \times 202013$

Untuk menganalisis data yang diperoleh dilakukan langkah-langkah sebagai berikut: (1) Menyiapkan dan mentranskrip data untuk dianalisis; (2) Membaca keseluruhan data; (3) Meng-coding data; (4) Menghubungkan hipotesis dengan bukti, munculnya berpikir intuitif; (5) Menyajikan data; (6) Menginterpretasikan munculnya berpikir intuitif; (7) Menarik kesimpulan

\section{Hasil dan Pembahasan}

Untuk memperoleh gambaran tentang berpikir intuitif setiap subjek, dipilih 1 soal sebagai instrumen penelitian. Selanjutnya akan dibahas berpikir intuitif 4 subjek dalam memecahkan masalah matematika. Berpikir intuitif yang terjadi merupakan solusi yang muncul pada saat siswa mengalami kesulitan untuk menyelesaikan soal matematika yang diberikan. Berikut ini dibahas hasil pemecahan masalah.

\subsection{Hasil Pemecahan Masalah Oleh Subjek 1}

Soal yang diberikan adalah: Berapakah hasil dari penjumlahan 202010×202012$202009 \times 202013$ ?

dan jawaban siswa adalah $202010 \times 202012-$ $202009 \times 202013=120-117=3$

Pemecahan masalah yang dihasilkan oleh S1 memunculkan berpikir intuitif yang didukung oleh faktor-faktor pendukung munculnya berpikir intuitif. Berpikir intuitif terjadi ketika siswa memutuskan untuk mencoret angka-angka yang sama dari keempat bilangan yang dioperasikan. Angka yang sama pada keempat bilangan adalah 2020. Kemudian perhitungan aljabar biasa dilakukan yaitu 12 × 10 dikurangi 09 x 13 dan hasil yang diperoleh adalah 3. Dalam memahami masalah, tidak digunakan suatu proses tertentu, seperti ilustrasi atau gambar. Ini menunjukkan bahwa S1 langsung memahami masalah yang diberikan.

Berdasarkan hasil pekerjaan dan wawancara, dapat disimpulkan bahwa S1 menggunakan cara berpikir intuitif. S1 tidak menggunakan cara panjang dalam menghitung atau membuat cakaran jawaban terlebih dahulu. Hasil wawancara menunjukkan bahwa pemahaman secara langsung ini bukan karena S1 telah memiliki pengalaman melakukan pemecahan masalah seperti yang diberikan oleh peneliti atau pernah membaca tulisan tentang permasalahan yang sama, akan tetapi dalam pemahaman masalah benarbenar diperoleh $\mathrm{S} 1$ sesaat setelah membaca teks masalah. Jika dikaitkan dengan pendapat Fischbein (1987) maka hal ini terdapat pada intuisi afirmatory komponen yang pertama, yaitu untuk memahami masalah digunakan kognisi langsung (self efident), artinya kognisi yang diterima langsung oleh individu tanpa membutuhkan pengecekan dan pembuktian lebih lanjut. Dalam pandangan Kustos (2010), terdapat komponen insting pada S1 yaitu munculnya respon untuk memahami masalah yang dihadapi.

Berpikir intuitif yang dimunculkan berupa ide secara tiba-tiba sebagai strategi dalam membuat keputusan berdasarkan feeling, intrinsik dan intervensi sehingga menghasilkan jawaban pada pemecahan masalah yang dihadapi. Menurut pendapat Fischbein (1987) S1 menggunakan intuisi antisipatory yaitu penyelesaian masalah bertentangan dengan dugaan pada umumnya, artinya bahwa S1 melakukan klaim suatu prosedur yang tidak biasa, namun S1 merasa klaim, yang dihasilkannya itu benar. Sedangkan jika dikaitkan dengan pendapat Kustos (2010) cara yang digunakan oleh S1 ini termasuk dalam komponen persepsi dan global, karena S1 menghasilkan solusi jawaban dengan benar.

\subsection{Hasil Pemecahan Masalah Oleh Subjek 2}

Soal yang diberikan adalah: Berapakah hasil dari penjumlahan $202010 \times 202012$ $202009 \times 202013$ ?

dan jawaban siswa adalah $202010 \times 202012-$ $202009 \times 202013=120-117=3$ 
Berpikir intuitif yang dihasilkan S2 dalam Pemecahan masalah mirip dengan S1 yaitu ketika siswa memutuskan untuk mengambil 2 angka belakang dari setiap bilangan yang diberikan dalam soal. Kemudian siswa melakukan perhitungan dan diperoleh 120 - 117 yang menghasilkan 3. S2 memahami masalah secara langsung dan dilanjutkan dengan melakukan pemecahan masalah seperti yang diberikan. Hal ini jika dihubungkan dengan teori yang dirujuk oleh peneliti yaitu dari pendapat Fischbein (1987) dan Kustos (2010) berpikir intuitif S2 sama seperti yang terjadi pada S1.

Berdasarkan hasil pemecahan masalah yang dilakukan oleh S2 pada masalah ini, dapat disimpulkan bahwa S2 menggunakan cara berpikir intuitif. Berpikir intuitif didasarkan pada feeling, intrinsik dan intervensi sehingga menghasilkan jawaban tanpa adanya coretan terlebih dahulu. Berdasarkan pendapat Fischbein (1987), S2 menggunakan intuisi antisipatory yaitu penyelesaian masalah bertentangan dengan dugaan pada umumnya, artinya bahwa prosedur yang tidak biasa digunakan siswa dan menghasilkan klaim yang benar. Dalam pandangan Kustos (2010), S2 menggunakan komponen persepsi dan global, karena solusi jawaban yang akan dihasilkan dipersepsi terlebih dahulu oleh siswa, kemudian diselesaikan sampai memperoleh hasil.

\subsection{Hasil Pemecahan Masalah Oleh Subjek 3}

Soal yang diberikan adalah: Berapakah hasil dari 202010×202012 - 202009×202013?

dan jawaban siswa adalah

$202010 \times 202012-202009 \times 202013$

$$
=120-117=3
$$

Berpikir intuitif dimunculkan S3 dalam pemecahan masalah dengan mencoret 2 angka pertama dari setiap bilangan. Setelah itu, karena masih ada 2 angka yang sama, S3 mencoret lagi. Jadi S3 melakukan dua kali pencoretan untuk masing-masing bilangan, kemudian angka-angka yang sisa dalam setiap kelompok bilangan dihitung dan menghasilkan jawaban yang sama seperti yang diperoleh S1 dan S2. Dalam kaitannya dengan pendapat Fischbein (1987), terdapat pada intuisi afirmatory yaitu untuk memahami masalah digunakan kognisi langsung (self efident), Sedangkan menurut pandangan Kustos (2010), terdapat pada komponen insting, yang artinya S3 memahami masalah dengan memunculkan respon dalam berpikir terhadap masalah yang sedang dihadapi.
Berdasarkan hasil pemecahan masalah yang dilakukan oleh S3 pada masalah ini, dapat disimpulkan bahwa S3 menggunakan cara berpikir intuitif, sehingga menghasilkan jawaban pada pemecahan dengan cara yang sesuai pada hasil tulisannya di atas. Proses berpikir yang dihasilkan pada pemecahan masalah digambarkan bahwa S3 mengikuti cara berpikir intuitif. Jika dikaitkan dengan teori yang dirujuk oleh peneliti, maka pada pendapat Fischbein (1987) menggunakan intuisi antisipatory yaitu penyelesaian masalah bertentangan dengan dugaan pada umumnya, artinya bahwa siswa melakukan klaim suatu pernyataan, cara atau prosedur yang tidak biasa, namun siswa merasa klaim, cara atau prosedur yang dihasilkannya itu benar. Sedangkan jika pendapat Kustos (2010) cara yang digunakan oleh S3 ini termasuk dalam komponen persepsi dan global.

\subsection{Hasil Pemecahan Masalah Oleh Subjek 4}

Soal yang diberikan adalah: Berapakah hasil dari $202010 \times 202012-202009 \times 202013$ ?

dan jawaban siswa adalah

$$
\begin{aligned}
& 202010 \times 202012-202009 \times 202013 \\
= & z \theta 10 \times z \theta 12-z 009 \times z \theta 13 \\
= & 10 \times 12-9 \times 13 \\
= & 120-117=3
\end{aligned}
$$

Pemecahan masalah yang dihasilkan oleh S4 memunculkan berpikir intuitif pada saat siswa menentukan untuk mencoret bilangan-bilangan yang sama dari keempat kelompok bilangan yang dioperasikan yaitu bilangan depan dua angka yaitu angka 20. Selanjutnya siswa menuliskan 6 bilangan sisa, untuk dioperasikan. Karena masih ada bilangan yang sama kemudian dicoret lagi 2 bilangan yang sama pada setiap kelompok bilangan. Selanjutnya dilakukan perhitungan aljabar biasa yaitu $12 \times 10$ dikurangi $09 \times 13$ sehingga memperoleh hasil 3.

Berdasarkan hasil pemecahan masalah yang dilakukan oleh S4 pada masalah ini, dapat disimpulkan bahwa S4 menggunakan cara berpikir intuitif . Berpikir intuitif pada pemecahan masalah yang dihadapi digambarkan seperti di atas, saat S4 menyelesaikan masalah. Jika dikaitkan dengan teori yang dirujuk oleh peneliti, maka pada pendapat Fischbein (1987) menggunakan intuisi antisipatory yaitu penyelesaian masalah bertentangan dengan dugaan pada umumnya, artinya bahwa siswa melakukan klaim dan klaim, yang dihasilkannya itu benar. Sedangkan jika dikaitkan dengan pendapat Kustos (2010) cara yang digunakan oleh S1 ini termasuk dalam 
komponen persepsi dan global, karena siswa melakukan persepsi terhadap solusi jawaban yang akan dihasilkan, kemudian diselesaikan sampai memperoleh hasil.

\section{Kesimpulan}

Berdasarkan hasil penelitian disimpulkan bahwa adanya bentuk berpikir intiutif dalam menyelesaikan masalah yang muncul dalam menyelesaikan masalah matematika yaitu (1) intuisi afirmatory yaitu untuk memahami masalah digunakan kognisi langsung dan (2) komponen persepsi dan global, karena siswa melakukan persepsi terhadap solusi jawaban yang akan dihasilkan, kemudian diselesaikan sampai memperoleh hasil. Ada 3 proses saat siswa berpikir intuitif dalam menyelesaikan masalah matematika yaitu feeling, intrinsik, dan intervensi. Ketiga proses yang muncul saat siswa berpikir intuitif dapat mempermudah siswa menyelesaikan masalah matematika.

Siswa yang berpikir intuitif dalam menyelesaikan masalah matematika dapat memberikan manfaat yang cukup baik dalam meningkatkan pemahaman masalah matematika yang berakhir dengan meningkatnya hasil belajar siswa. Hal ini dapat memberikan salah satu solusi untuk mengatasi rendahnya prestasi belajar matematika.

\section{Daftar Pustaka}

Admin. (2013. Intuition and critical thinking. Articles Tab, K-12 instruction strategies. Bookmark the permalink. university of New Mexico.

Arifin (1998). Proses Komunikasi antara Pendidik dan Anak Didik. Jakarta: UT

Creswell, John W. (2012). Designing and Conducting Mixed Methods Research. USA: Sage publication, Inc.

Fischbein, E. (1987). Intuition in science and mathematics An educational approach, Reidel, The Netherlands

Freudenthal, H. (1991). Refisiting mathematics education. China Lectures. Dordrecht: Kluwer

Henden, G. 2004. Intuition and Its Role in Srategi Thingking. Unpublished Dissertation. BI Norwegian. Sage Publications, Inc.

Herry, Debra. (2007). Developing Thinking Developing Learning. Poland: Open University Press.

Hudoyo, H. (2008). Mengajar Belajar Matematika. Dirjen Dikti, Jakarta, Depdikbud.
Kemp, Jerold E, alih bahasa: Asril Marjohan (1994). Proses Perancangan Pengajaran. Bandung: ITB Bandung.

Kustos, P.N. 2010. Trens Concerning Four Misconception In Students' Intuitively-Based Probabilistic Reasoning Sourced In The Heuristic Of Representativeness. (http//udini.proquest.com/view/trendsconcerning-four). Di akses 13 April 2013.

Marpaung, Y. (2001). Prospek RME untuk Pembelajaran Matematika. Makalah disampaikan pada seminar nasional PMRI di Universitas Sanata Dharma, Yogyakarta 14-15

Moleong, Lexy, J. 2006. Metodologi Penilaian Kualitatif, Direktorat Jenderal Pendidikan Tinggi. Departemen Pendidikan Nasional. Bandung.

Peter, M. (2008). A Study of "Open - Approach" Method in School Mathematics Teaching Focusing On Mathematical Problem Solving Activities

http://www.nku.edu/ sheffield/nohda.html. [13 Oktober 2014].

Sao, Sofia. 2014. Berpikir Intuitif Dalam Pembelajaran Matematika. Prosiding Seminar Nasiona TEQIP (Teachers Quality Improvement Program) Membangun Karakter Bangsa melalui Pembelajaran Bermakna Universitas Negeri Malang 2014.

Slavin, Robert E. (1994). Educational Psychology: Theories and Practiece, Fourt Edition. Masschussets: Allyn and Bacon Publishers.

Soedjadi, R. (2001). Masalah kontekstual sebagai batu sendi matematika sekolah. Departemen Pendidikan Nasional UNESA. Surabaya.

Soedjadi, R. (2006). Kiat Pendidikan Matematika di Indonesia. Dirjen Dikti. Jakarta Depdikbud.

Solso Robert L., (2012) Psikologi Kognitif. Jakarta: Erlangga,

Taplin, A. (2010). Extensional versus intuitive reasoning: The conjunction fallacy in probability judgment. Psychological Review, 90(4), 293315 .

Usodo, Budi. (2011). Karakteristik Intuisi Siswa SMA dalam Memecahkan Masalah Matematika Ditinjau dari Kemampuan Matematika dan Perbedaan Gender. Surakarta: Perpustakaan FKIP UNS.

Voskoglou, Michael Gr. (2006). Formalism and intuition in mathematics: The role of the problem. Quaderni di Ricerca in Didattica. Italy

Weintraup, E. (1998). Awakening Intuition. New York: Anchor Books.

Yuwono, Ipung. 2001. RME (Realistic Mathematics Education) dan hasil Studi awal Implementasinya dan SLTP. Makalah disajikan pada Seminar Nasional Realistic Mathematics Education (RME) dan Jurusan FMIPA UNESA tanggal 24 Februari 2001. 